\title{
Giant Cell Arteritis and COVID-19: Similarities and Discriminators. A Systematic Literature Review
}

\author{
Puja Mehta ${ }^{1}(\mathbb{D})$, Sebastian E. Sattui ${ }^{(\mathbb{D}}$, Kornelis S.M. van der Geest ${ }^{3}(\mathbb{D})$, Elisabeth Brouwer ${ }^{3}(\mathbb{D})$, \\ Richard Conway ${ }^{4}$, Michael S. Putman ${ }^{5}$, Philip C. Robinson ${ }^{6}$, and Sarah L. Mackie ${ }^{7}$
}

\begin{abstract}
Objective. To identify shared and distinct features of giant cell arteritis (GCA) and coronavirus disease 2019 (COVID-19) to reduce diagnostic errors that could cause delays in correct treatment.

Methods. Two systematic literature reviews determined the frequency of clinical features of GCA and COVID-19 in published reports. Frequencies in each disease were summarized using medians and ranges.

Results. Headache was common in GCA but was also observed in COVID-19 (GCA 66\%, COVID-19 $10 \%$ ). Jaw claudication or visual loss ( $43 \%$ and $26 \%$ in GCA, respectively) generally were not reported in COVID-19. Both diseases featured fatigue (GCA 38\%, COVID-19 43\%) and elevated inflammatory markers (C-reactive protein [CRP] elevated in 100\% of GCA, 66\% of COVID-19), but platelet count was elevated in $47 \%$ of GCA but only $4 \%$ of COVID-19 cases. Cough and fever were commonly reported in COVID-19 and less frequently in GCA (cough, 63\% for COVID-19 vs 12\% for GCA; fever, $83 \%$ for COVID-19 vs 27\% for GCA). Gastrointestinal upset was occasionally reported in COVID-19 (8\%), rarely in GCA (4\%). Lymphopenia was more common in COVID-19 than GCA (53\% in COVID-19, 2\% in GCA). Alteration of smell and taste have been described in GCA but their frequency is unclear.

Conclusion. Overlapping features of GCA and COVID-19 include headache, fever, elevated CRP and cough. Jaw claudication, visual loss, platelet count and lymphocyte count may be more discriminatory. Physicians should be aware of the possibility of diagnostic confusion. We have designed a simple checklist to aid evidence-based evaluation of patients with suspected GCA.
\end{abstract}

Key Indexing Terms: coronavirus, diagnosis, giant cell arteritis

PM is a clinical training fellow within the Medical Research CouncilGlaxoSmithKline (MRC-GSK) Experimental Medicine Initiative to Explore New Therapies network and receives project funding unrelated to this work. $P M$ also receives cofunding from the National Institute for Health Research (NIHR) University College London Hospitals Biomedical Research Centre. MP is supported in part by Grant Number T32 AR007611-13 from the National Institute of Arthritis and Musculoskeletal and Skin Diseases (NIAMS). SES received funding from the Vasculitis Clinical Research Consortium (VCRC)/Vasculitis Foundation Fellowship. The VCRC is part of the Rare Diseases Clinical Research Network, an initiative of the Office of Rare Diseases Research, National Center for Advancing Translational Science (NCATS). The VCRC is funded through collaboration between NCATS, and NIAMS (U54 AR057319). SLM receives infrastructure support from the MRC TARGET Partnership Grant (MR/N011775/1/MRC_/Medical Research Council/United Kingdom) and from the NIHR Leeds Biomedical Research Centre. The views expressed are those of the authors and not necessarily those of the NIHR or the Department of Health and Social Care. ${ }^{1} P$. Mehta, Rheumatology Fellow, MD, Centre for Inflammation and Tissue Repair, UCL Respiratory, Division of Medicine, University College London, Department of Rheumatology, University College London Hospital (UCLH) NHS Trust, London, UK; ${ }^{2}$ S.E. Sattui, Rheumatology Fellow, $M D$, Division of Rheumatology, Department of Medicine, Hospital for Special Surgery, New York, NY, USA; ${ }^{3}$ K. van der Geest, Rheumatology Fellow, PhD, E. Brouwer, Internist Rheumatologist, Associate Professor, PhD, Department of Rheumatology and Clinical Immunology, University of Groningen, University Medical Center Groningen, Groningen, the Netherlands; ${ }^{4} R$. Conway, Consultant Rheumatologist, PhD, Department of Rheumatology, St. James's Hospital, Dublin, Ireland; ${ }^{5}$ M.S. Putman, Clinical Instructor of Medicine, MD, Division of Rheumatology, Department of Medicine, Northwestern University, Chicago, IL, USA; ${ }^{\circ}$. Robinson, Associate Professor, PhD, University of Queensland Faculty of Medicine, Brisbane, Australia; ${ }^{7}$ S.L. Mackie, Associate Clinical Professor and Honorary Consultant Rheumatologist, PhD, Leeds Institute of Rheumatic and Musculoskeletal Medicine, University of Leeds, and NIHR Leeds Biomedical Research Centre, Leeds Teaching Hospitals NHS Trust, Leeds, UK.

P. Mehta, S.E. Sattui, and K. van der Geestmade equal contributions to this work.

$K S M v d G$ received a speaker fee from Roche (2019) paid to the UMCG. EB received consultancy and speaker fees from Roche (2017 and 2018) paid to the UMCG. PR reports no competing interests related to this work, outside of this work he reports personal consulting and/or speaking fees from AbbVie, Eli Lilly, Janssen, Novartis, Pfizer and UCB and travel assistance from Roche. $S L M$ received consultancy fees from Roche (2015) and was supported by Roche to attend EULAR 2019. She has acted as investigator on clinical trials in GCA for Sanofi, Roche and GSK. Consultancy fees from Roche (2016, 2018) and Sanofi (2017) were paid to her institution. She is Patron of the UK charity Polymyalgia Rheumatica \& Giant Cell Arteritis UK. RC, PM, MSP, SES have no conflicts of interest declared.

Address correspondence to Dr. S.L. Mackie, Leeds Institute of Rheumatic and Musculoskeletal Medicine, Chapel Allerton Hospital, Harrogate Road, Leeds LS74SA,UK.Email:s.l.mackie@leeds.ac.uk.

Open Access Article. For details see Reprints and Permissions at jrheum.org. Accepted for publication September 29, 2020. 
Giant cell arteritis (GCA) is the most common form of systemic vasculitis and typically affects patients over the age of 50. GCA is still little known among the general public and the diagnosis is usually first suspected by a physician, most frequently in evaluating new-onset headaches. Laboratory tests typically show an acute-phase response and rheumatologists play a key role in diagnostic confirmation. This is one of the most time-critical decisions in rheumatology: Failure to treat may result in blindness, but misdiagnosis of GCA can lead to inappropriate immunosuppression and a missed opportunity to treat the real underlying cause of the symptoms. The coronavirus disease 2019 (COVID-19) pandemic has presented new challenges in the evaluation of patients with suspected GCA, including the need to direct patients by either "hot" or "cold" pathways to minimize inadvertent transmission of SARS-CoV-2.

During much of the current pandemic, the incidence of COVID-19 in the community has been higher than that of GCA in many places. Early public health messages emphasized fever, cough, and shortness of breath as COVID-19 indicators, with alteration in taste/smell having been subsequently added. Anecdotally, we saw patients referred for evaluation of GCA who turned out to have COVID-19-related headaches while, conversely, patients with persistent fever who were initially thought to have COVID-19 were only suspected to have GCA after prolonged investigations for infection. Guidelines advise specialist evaluation of suspected GCA within 24 hours and confirmation of the diagnosis by vascular ultrasound or temporal artery biopsy (TAB), but during the COVID-19 pandemic, the close, sustained personal contact with a healthcare practitioner during either of these procedures carries potential risk for both individuals. There is now an imperative for physicians to differentiate between GCA symptoms and COVID-19 symptoms and to conduct a risk assessment before the ultrasound scan takes place. We reviewed the literature to gather the best available evidence on features that may discriminate between the 2 conditions.

\section{METHODS}

We performed 2 systematic literature reviews. Searches were carried out by 2 independent reviewers and discrepancies were resolved by wider consensus.

For the GCA literature review, a general search strategy for the diagnostic features of GCA had already been devised for a previous systematic review and metaanalysis (Supplementary Methods, available with the online version of this article) and was updated on April 5, 2020. We searched PubMed, Embase, and the Cochrane Database of Systematic Reviews to identify studies recruiting consecutive patients with suspected GCA. The preferred reference standard was $\mathrm{TAB}$ or vascular imaging, but studies using a reference standard of clinical diagnosis were included if $\geq 75 \%$ of the patients clinically diagnosed with GCA had positive TAB or vascular imaging to confirm this diagnosis. For this review, we selected the 4 largest studies that reported the frequency of each symptom. However, for less typical GCA features and laboratory tests with limited data available, we also performed a directed search in PubMed to obtain data from other study types reporting these features in patients with GCA.

For the COVID-19 review, we identified all cohorts or case series published between January 1, 2020, and April 5th, 2020, that described patients diagnosed with COVID-19. We excluded retrospective case series of $<50$ patients, and reports in which the patients had all died, were all in the intensive care unit, or had a particular comorbidity (e.g., cancer). PubMed, Embase, and the Cochrane Database of Systematic Reviews were all searched. References from included studies as well as the NCBI database LitCovid (www.ncbi.nlm.nih.gov/research/coronavirus) were searched to identify other potentially eligible studies. We did not review the frequency of hypoxemia and tachypnea since, in the context of our review, these symptoms would have been likely to prompt further investigation and treatment for respiratory pathology.

For each selected publication, we extracted the reported frequencies of each symptom, sign, or laboratory feature, and determined the median and range for the publications reviewed. Comparing the 2 diseases, we divided the features into those more typical of GCA, those more typical of COVID-19, and those observed in both. Risk of bias assessment was performed independently by 2 authors using the Institute for Health Economics quality appraisal checklist for case series studies (IHE, Edmonton, Alberta, 2014: www.ihe.ca/research-programs/rmd/cssqac/cssqac-about), which can be found in the Supplementary Material (available with the online version of this article). Any differences were adjudicated by a third author.

\section{RESULTS}

A general search strategy for diagnostic features of GCA and additional directed searches yielded 1666 unique hits (Supplementary Methods, available with the online version of this article). Of these, 35 studies were included for analysis, of which 30 studies were selected from the general search strategy and the remaining 5 studies had been identified by the additional directed searches. Limited or no published data on the frequency of lymphopenia or thrombocytopenia in GCA were found; therefore, 2 coauthors reanalyzed raw data from a previously published study ${ }^{1}$.

From the COVID literature review, 211 studies were identified. After screening the title and abstract of each paper, 33 full texts were selected for review. Of these, 29 studies comprising 5623 patients were included in this analysis. One additional study ${ }^{2}$, published after the updated search was concluded, was identified and included to provide information on the frequency of altered sense of smell or taste that had not been identified through the general search strategy. This study also included data regarding vision impairment.

The main findings are presented in Table 1 and summarized in Figure 1. The overall risk of bias in the included studies ${ }^{1-67}$ was moderate; details can be found in the Supplementary Material (available with the online version of this article). The main issue identified in the COVID-19 studies was that these studies were almost all restricted to hospitalized patients who were at various stages of disease. Since the most common reason for hospitalization is respiratory symptoms, these may have been overrepresented in the literature, and nonrespiratory symptoms underrepresented, compared to patients with COVID-19 presenting from the community. With regard to the GCA studies, the majority of studies were retrospective and involved collection of data from medical records, sometimes over many decades. In addition, the stated aim of many of the GCA studies was not to describe the features of the disease, but instead focused on a particular research question. The description of GCA features appeared to be largely intended to show that the "core" GCA features were similar to those in previously published studies. The frequency of headache was always reported in the 
Table 1. Frequency of symptoms, physical signs, and laboratory abnormalities in GCA and COVID-19.

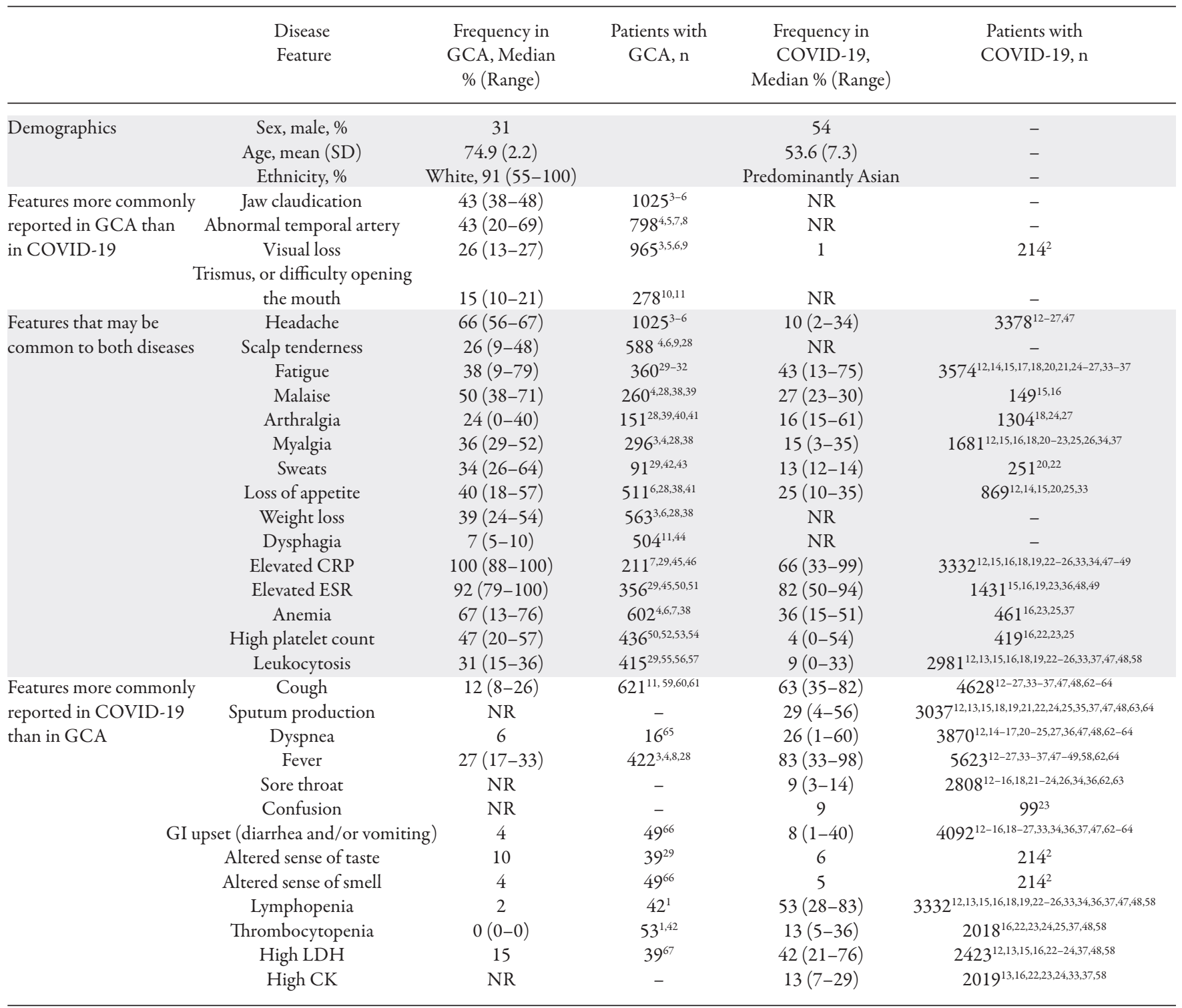

Comparison between the frequency of disease features reported in the GCA literature and those in COVID-19 literature. Differences in the reporting of some of these features between the different diseases necessitated some subjective decisions in the presentation of the data. The frequency of scalp tenderness is unknown in COVID-19, but even during the pre-COVID era, scalp tenderness was common in patients referred with GCA who were not ultimately diagnosed with this disease (according to the classic metaanalysis of Smetana and Shmerling ${ }^{71}$, scalp tenderness is present in around 1 in 4 patients with suspected GCA who are not ultimately diagnosed with this disease). Therefore, we made the conservative decision to present scalp tenderness here as a feature that might be common in both diseases. The "fatigue" category presented here does not include 8 COVID-19 studies reporting "fatigue or myalgia," since it was not possible to separate the 2 symptoms from data presented in those publications. CK: creatine kinase; COVID-19: coronavirus disease 2019; CRP: C-reactive protein; ESR: erythrocyte sedimentation rate; GCA: giant cell arteritis; GI: gastrointestinal; LDH: lactate dehydrogenase; NR: not reported.

GCA studies, for example, but the frequency of cough was rarely reported. In the COVID-19 studies, the frequency of cough was reported in 26/29 studies and headache in 17/29 studies, but some symptoms, such as myalgia/arthralgia, were less precisely defined than in the rheumatology literature.

\section{DISCUSSION}

In the > 50 age group, GCA and COVID-19 may initially present with similar symptoms. As reported in a recent systematic review and metaanalysis ${ }^{68}$, only around 2 of 3 patients with
GCA report headache, while around 1 of 4 report fever. In the COVID-19 studies we identified, headache is reportedly present in $2-34 \%$ and fever in $83 \%$ of patients. Acute-phase response is common in both conditions. Thrombocytosis may point more towards GCA, and lymphopenia towards COVID-19.

The possibility of reporting bias is important when interpreting these data: in large, single-disease cohorts, structured data collection tends to focus on features considered typical of the disease in question. Historically, dry cough has been underrecognized as a symptom of GCA, and it was reported in 


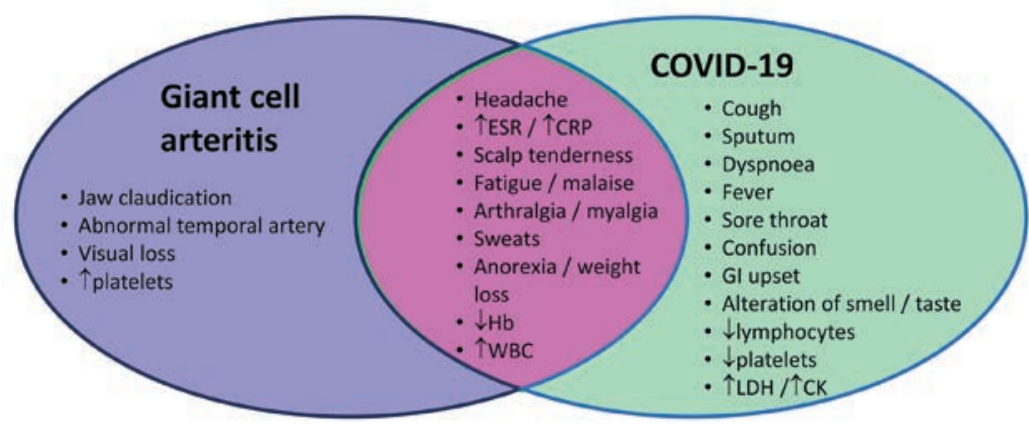

Figure 1. Features of giant cell arteritis and COVID-19 based on reported frequencies. This Venn diagram represents features that are more commonly reported in GCA or COVID-19, and features that may be seen in both conditions (overlapping section). Headache and elevated inflammatory markers (in the dotted box), often considered the cardinal features of GCA, may be observed in both GCA and COVID-19. CK: creatine kinase; COVID-19: coronavirus disease 2019; CRP: C-reactive protein; ESR: erythrocyte sedimentation rate; GCA: giant cell arteritis; GI: gastrointestinal (diarrhea or vomiting); $\mathrm{Hb}$ : hemoglobin; $\mathrm{LDH}$ : lactate dehydrogenase; WBC: white blood cell count.
Patient NHS no:

\begin{tabular}{|c|c|c|c|}
\hline $\begin{array}{l}\text { Male } \\
\text { Female }\end{array}$ & Age: $\begin{array}{l} \\
\\
50-60 \\
61-65 \\
66+\end{array}$ & $\begin{array}{c}\text { Symptom duration: } \\
12-24 \text { weeks } \\
6-12 \text { weeks } \\
<6 \text { weeks } \\
\end{array}$ & \begin{tabular}{|c|} 
COVID19 risk: \\
Work \\
Home \\
Hobbies
\end{tabular} \\
\hline & GCA & GCA/COVID & COVID \\
\hline & $\begin{array}{l}\text { Jaw claudication } \\
\text { Hard to open mouth } \\
\text { Tongue claudication }\end{array}$ & $\begin{array}{l}\text { Headache } \\
\text { Neck pain } \\
\text { Scalp tenderness } \\
\text { Stroke } \\
\text { TIA } \\
\end{array}$ & $\begin{array}{l}\text { Sore throat } \\
\text { Hoarse voice } \\
\text { Loss smell/taste } \\
\text { Confusion } \\
\text { Dizziness } \\
\end{array}$ \\
\hline & $\begin{array}{l}\text { Transient visual loss } \\
\text { Diplopia } \\
\text { Visual fatigue }\end{array}$ & & $\begin{array}{l}\text { Red eye } \\
\text { Watery eye } \\
\text { Chemosis } \\
\end{array}$ \\
\hline & $\begin{array}{l}\text { Shoulders stiff+achy } \\
\text { Hips stiff+achy }\end{array}$ & $\begin{array}{l}\text { Back pain } \\
\text { Myalgia } \\
\text { Gen. arthralgia }\end{array}$ & Chilblains finger/toe \\
\hline & Weight loss & Loss of appetite & $\begin{array}{l}\text { Vomiting } \\
\text { Diarrhoea } \\
\text { Abdominal pain }\end{array}$ \\
\hline & Arm claudication & Tingling hands/feet & $\begin{array}{l}\text { Cough } \\
\text { Sputum } \\
\text { Shortness of breath } \\
\text { Chest pain } \\
\text { Palpitations } \\
\text { Haemopytsis }\end{array}$ \\
\hline & & $\begin{array}{l}\text { Sweats } \\
\text { Fatigue } \\
\text { Malaise }\end{array}$ & $\begin{array}{l}\text { Rash } \\
\text { Fever/chills } \\
\text { Rigors } \\
\end{array}$ \\
\hline $\begin{array}{c}\text { exam } \\
\text { vital signs }\end{array}$ & $\begin{array}{l}\text { Thickened TA } \\
\text { Nodular TA } \\
\text { Pulseless TA } \\
\text { Scalp necrosis } \\
\text { Bruit } \\
\text { Cranial nerve palsy } \\
\text { AION } \\
\text { CRAO } \\
\text { Visual field loss } \\
\end{array}$ & Tender TA & $\begin{array}{l}\text { High temp } \\
\text { High HR } \\
\text { High RR } \\
\text { Low BP }\end{array}$ \\
\hline & $\begin{array}{l}\text { High platelets } \\
\text { High monocytes }\end{array}$ & $\begin{array}{l}\text { CRP } 6 \text { to } 10 \\
\text { CRP } 11 \text { to }<25 \\
\text { CRP } 25+ \\
\text { Elevated ESR } \\
\text { Elevated PV } \\
\text { Low Hb }\end{array}$ & $\begin{array}{l}\text { Low lymphocytes } \\
\text { Low eosinophils } \\
\text { Low platelets } \\
\text { High D-dimer } \\
\text { High LDH } \\
\text { High CK } \\
\text { Acute kidney injury }\end{array}$ \\
\hline
\end{tabular}

Clinical probability of GCA (>50\%/20-50\%/<20\%)
Figure 2. A checklist to support evidence-based history and examination in evaluation of patients with suspected giant cell arteritis. This checklist was constructed in an Excel spreadsheet, informed by the findings of the literature review presented here. The checklist is primarily intended to aid clinicians who are conducting a telephone consultation with a patient referred with suspected giant cell arteritis, prior to their face-to-face appointment during the COVID-19 pandemic. There is also space for relevant physical examination findings and laboratory test results to be added, if provided by the referrer. This checklist has been piloted in Leeds, UK, where it has been further customized to allow the automated generation of relevant alerts (by conditional formatting) and risk scores (based on local audit data and the published literature) to support clinical decision making. AION: anterior ischemic optic neuropathy; BP: blood pressure; CRAO: central retinal artery occlusion; CK: creatine kinase; COVID19: coronavirus disease 2019; CRP: C-reactive protein; ESR: erythrocyte sedimentation rate; GCA: giant cell arteritis; Gen: general; Hb: hemoglobin; HR: heart rate; $\mathrm{LDH}$ : lactate dehydrogenase; NHS: National Health Service (UK); PV: plasma viscosity; RR: respiration rate; TA: Takayasu arteritis; TIA: transient ischemic attack. 
only a minority of studies we identified ${ }^{11,32,59,60,61,65,67}$. Patients presenting with new-onset GCA should be evaluated for cough, since this might be associated with involvement of the aorta and its proximal branches, which is a potential risk factor for relapse or aortic aneurysm in GCA; however, this hypothesis requires testing.

We were limited by not being able to stratify GCA by symptom duration. The average reported symptom duration in GCA is 9 weeks, but this is highly variable. On average, symptom duration is somewhat longer in nonheadache presentations, and shorter in those with isolated cranial symptoms ${ }^{69}$. The average duration of COVID-19 symptom onset to admission was typically $1-2$ weeks in these studies ${ }^{20,22,37,58}$, but this may differ outside of China.

Most of the COVID-19 data in our review came from hospitalized cases in China. According to the World Health Organization-China Joint Mission report, published February 28, 2020, even mild COVID-19 cases were compulsorily removed to either Fangcang shelter hospitals or acute hospitals designated for COVID-19. Patients $>65$ or with a comorbidity such as hypertension were not eligible for care in Fangcang hospitals and instead were admitted to acute hospitals. The average age of patients in the studies we identified was 53.6 years. At that time, anosmia was not universally recognized as a COVID-19 symptom and so it appears in few publications from this period. This illustrates that it cannot be assumed a symptom not reported in a disease is always absent. We surmise, however, that it is likely that the most prominent features of any disease will be the ones reported; therefore, our findings are likely to remain clinically relevant. For features less typical of GCA, if larger studies did not report the frequency of these features, a compromise was reached by including additional small studies, one of which also included polymyalgia rheumatica ${ }^{66}$.

Our review raises new research questions that are testable by prospectively collecting data during the current pandemic. First, in patients presenting with headache due to COVID19 , what is the frequency of "GCA-like" features, such as scalp tenderness, temporal artery tenderness, difficulty chewing, transient visual loss, weight loss, dysphagia, or trismus in patients? Second, in patients presenting with GCA, what is the frequency of "COVID-19-like" features such as dry cough, sore throat, dyspnea, confusion, anosmia or alteration in sense of taste $e^{2,70}$, lymphopenia, thrombocytopenia, elevation in lactate dehydrogenase, or elevation in creatine kinase? Third, given that most of the data on COVID-19 symptom patterns identified in this review come from China, is there variation in the clinical presentation of COVID-19 according to ethnicity or culture? Fourth, how does the clinical picture of GCA patients presenting with a short symptom duration (days-weeks) differ from those presenting with a long symptom duration (months-years)? Last, is cough at presentation of GCA associated with an increased relapse risk?

It has always been true that most new-onset headaches will not be due to GCA, and many will be due to minor viral infections; however, the novel situation at the time of writing is that currently, many new-onset headaches may be due to COVID-19.
Based on the evidence we identified in our literature search, we have designed a simple clinical checklist (Figure 2) that could aid clinicians in assessing patients with suspected GCA during the COVID-19 pandemic, as well as in generating data that might answer some of the research questions identified here.

\section{ONLINE SUPPLEMENT}

Supplementary material accompanies the online version of this article.

\section{REFERENCES}

1. van Sleen Y, Graver JC, Abdulahad WH, van der Geest KS, Boots AM, Sandovici M, et al. Leukocyte dynamics reveal a persistent myeloid dominance in giant cell arteritis and polymyalgia rheumatica. Front Immunol 2019;10:1981.

2. Mao L, Jin H, Wang M, Hu Y, Chen S, He Q, et al. Neurologic manifestations of hospitalized patients with coronavirus disease 2019 in Wuhan, China. JAMA Neurol 2020;77:683-90.

3. González-López JJ, González-Moraleja J, Burdaspal-Moratilla A, Rebolleda G, Núñez-Gómez-Álvarez MT, Muñoz-Negrete FJ. Factors associated to temporal artery biopsy result in suspects of giant cell arteritis: a retrospective, multicenter, case-control study. Acta Ophthalmol 2013;91:763-8.

4. Hayreh SS, Podhajsky PA, Raman R, Zimmerman B. Giant cell arteritis: validity and reliability of various diagnostic criteria. Am J Ophthalmol 1997;123:285-96.

5. Ing EB, Miller NR, Nguyen A, Su W, Bursztyn L, Poole M, et al. Neural network and logistic regression diagnostic prediction models for giant cell arteritis: development and validation. Clin Ophthalmol 2019;13:421-30.

6. Younge BR, Cook BE Jr, Bartley GB, Hodge DO, Hunder GG. Initiation of glucocorticoid therapy: before or after temporal artery biopsy? Mayo Clin Proc 2004;79:483-91.

7. Marí B, Monteagudo M, Bustamante E, Pérez J, Casanovas A, Jordana R, et al. Analysis of temporal artery biopsies in an 18-year period at a community hospital. Eur J Intern Med 2009;20:533-6.

8. Gabriel SE, O'Fallon WM, Achkar AA, Lie JT, Hunder GG. The use of clinical characteristics to predict the results of temporal artery biopsy among patients with suspected giant cell arteritis. J Rheumatol 1995;22:93-6.

9. Hall S, Persellin S, Lie JT, O'Brien PC, Kurland LT, Hunder GG. The therapeutic impact of temporal artery biopsy. Lancet 1983;2:1217-20.

10. Nir-Paz R, Gross A, Chajek-Shaul T. Reduction of jaw opening (trismus) in giant cell arteritis. Ann Rheum Dis 2002;61:832-3.

11. Liozon E, Jauberteau MO, Ly K, Loustaud V, Soria P, Vidal E. Reduction of jaw opening in giant cell arteritis. Ann Rheum Dis 2003;62:287-8.

12. Chen T, Wu D, Chen H, Yan W, Yang D, Chen G, et al. Clinical characteristics of 113 deceased patients with coronavirus disease 2019: retrospective study. BMJ 2020;368:m1091.

13. Xu XW, Wu XX, Jiang XG, Xu KJ, Ying LJ, Ma CL, et al. Clinical findings in a group of patients infected with the 2019 novel coronavirus (SARS-Cov-2) outside of Wuhan, China: retrospective case series. BMJ 2020;368:m606.

14. Yan Y, Yang Y, Wang F, Ren H, Zhang S, Shi X, et al. Clinical characteristics and outcomes of patients with severe covid-19 with diabetes. BMJ Open Diabetes Res Care 2020;8:e001343.

15. Wang Z, Yang B, Li Q, Wen L, Zhang R. Clinical features of 69 cases with coronavirus disease 2019 in Wuhan, China. Clin Infect Dis 2020;71:769-77.

16. Wu J, Liu J, Zhao X, Liu C, Wang W, Wang D, et al. Clinical characteristics of imported cases of COVID-19 in Jiangsu province: A multicenter descriptive study. Clin Infect Dis 2020;71:706-712. 
17. Tian S, Hu N, Lou J, Chen K, Kang X, Xiang Z, et al. Characteristics of COVID-19 infection in Beijing. J Infect 2020;80:401-6.

18. Xu YH, Dong JH, An WM, Lv XY, Yin XP, Zhang JZ, et al. Clinical and computed tomographic imaging features of novel coronavirus pneumonia caused by SARS-CoV-2. J Infect 2020;80:394-400.

19. Zhu W, Xie K, Lu H, Xu L, Zhou S, Fang S. Initial clinical features of suspected coronavirus disease 2019 in two emergency departments outside of Hubei, China. J Med Virol 2020; 92:1525-32.

20. Wang D, Hu B, Hu C, Zhu F, Liu X, Zhang J, et al. Clinical characteristics of 138 hospitalized patients with 2019 novel coronavirus-infected pneumonia in Wuhan, China. JAMA 2020;323:1061-69.

21. Shi S, Qin M, Shen B, Cai Y, Liu T, Yang F, et al. Association of cardiac injury with mortality in hospitalized patients with COVID-19 in Wuhan, China. JAMA Cardiol 2020;5:802-10.

22. Yang W, Cao Q, Qin L, Wang X, Cheng Z, Pan A, et al. Clinical characteristics and imaging manifestations of the 2019 novel coronavirus disease (COVID-19): a multi-center study in Wenzhou city, Zhejiang, China. J Infect 2020;80:388-93.

23. Chen N, Zhou M, Dong X, Qu J, Gong F, Han Y, et al. Epidemiological and clinical characteristics of 99 cases of 2019 novel coronavirus pneumonia in Wuhan, China: a descriptive study. Lancet 2020;395:507-13.

24. Guan WJ, Ni ZY, Hu Y, Liang WH, Ou CQ, He JX, et al. Clinical characteristics of coronavirus disease 2019 in China. New Engl J Med 2020;382:1708-20.

25. Qian GQ, Yang NB, Ding F, Ma AHY, Wang ZY, Shen YF, et al. Epidemiologic and clinical characteristics of 91 hospitalized patients with COVID-19 in Zhejiang, China: a retrospective, multi-centre case series. QJM 2020;113:474-81.

26. Han R, Huang L, Jiang H, Dong J, Peng H, Zhang D. Early clinical and CT manifestations of coronavirus disease 2019 (COVID-19) pneumonia. AJR Am J Roentgenol 2020;215:338-43.

27. Mo P, Xing Y, Xiao Y, Deng L, Zhao Q, Wang H, et al. Clinical characteristics of refractory COVID-19 pneumonia in Wuhan, China. Clin Infect Dis 2020 March 16 (E-pub ahead of print).

28. Toren A, Weis E, Patel V, Monteith B, Gilberg S, Jordan D. Clinical predictors of positive temporal artery biopsy. Can J Opthalmol 2016;51:476-81.

29. Myklebust G, Gran JT. A prospective study of 287 patients with polymyalgia rheumatica and temporal arteritis: clinical and laboratory manifestations at onset of disease and at the time of diagnosis. Br J Rheumatol 1996;35:1161-8.

30. Baldursson O, Steinsson K, Björnsson J, Lie JT. Giant cell arteritis in Iceland. An epidemiologic and histopathologic analysis. Arthritis Rheum 1994;37:1007-12.

31. Kermani TA, Schmidt J, Crowson CS, Ytterberg SR, Hunder GG, Matteson EL, et al. Utility of erythrocyte sedimentation rate and C-reactive protein for the diagnosis of giant cell arteritis. Semin Arthritis Rheum 2012;41:866-71.

32. Hu Z, Yang Q, Zeng S, Li J, Wu X, Cao L, et al. Giant cell arteritis in China: a prospective investigation. Angiology 2002;53:457-63.

33. Zhang JJ, Dong X, Cao YY, Yuan YD, Yang YB, Yan YQ, et al. Clinical characteristics of 140 patients infected with SARS-CoV-2 in Wuhan, China. Allergy 2020;75:1730-41.

34. Cao J, Tu WJ, Cheng W, Yu L, Liu YK, Hu X, et al. Clinical features and short-term outcomes of 102 patients with coronavirus disease 2019 in Wuhan, China. Clin Infect Dis 2020;71:748-55.

35. Liu KC, Xu P, Lv WF, Qiu XH, Yao JL, Gu JF, et al. CT manifestations of coronavirus disease-2019: A retrospective analysis of 73 cases by disease severity. Eur J Radiol 2020;126:108941.

36. Chen J, Qi T, Liu L, Ling Y, Qian Z, Li T, et al. Clinical progression of patients with COVID-19 in Shanghai, China. J Infect 2020;80:e1-e6.

37. Zhou F, Yu T, Du R, Fan G, Liu Y, Liu Z, et al. Clinical course and risk factors for mortality of adult inpatients with COVID-19 in Wuhan, China: a retrospective cohort study. Lancet 2020; 395:1054-62.

38. Rodríguez-Pla A, Rosselló-Urgell J, Bosch-Gil JA, Huguet-Redecilla P, Vilardell-Tarres M. Proposal to decrease the number of negative temporal artery biopsies. Scand J Rheumatol 2007;36:111-8.

39. Vilaseca J, González A, Cid MC, Lopez-Vivancos J, Ortega A. Clinical usefulness of temporal artery biopsy. Ann Rheum Dis 1987;46:282-5.

40. Stuart RA. Temporary artery biopsy in suspected temporal arteritis: a five year survey. N Z Med J 1989;102:431-3.

41. Fernandez-Herlihy L. Temporal arteritis: Clinical aids to diagnosis. J Rheumatol 1988;15:1797-801.

42. Sundholm JKM, Pettersson T, Paetau A, Albäck A, Sarkola T. Diagnostic performance and utility of very high-resolution ultrasonography in diagnosing giant cell arteritis of the temporal artery. Rheumatol Adv Pract 2019;3:rkz018.

43. Hop H, Mulder DJ, Sandovici M, Glaudemans AWJM, van Roon AM, Slart RHJA, et al. Diagnostic value of axillary artery ultrasound in patients with suspected giant cell arteritis. Rheumatology 2020;2:keaa102.

44. Gonzalez-Gay MA, Vazquez-Rodriguez TR, Gomez-Acebo I, Pego-Reigosa R, Lopez-Diaz MJ, Vazquez-Triñanes MC, et al. Strokes at time of disease diagnosis in a series of 287 patients with biopsy-proven giant cell arteritis. Medicine 2009;88:227-35.

45. Gonzalez-Gay MA, Lopez-Diaz MJ, Barros S, Garcia-Porrua C, Sanchez-Andrade A, Paz-Carreira J, et al. Giant cell arteritis: laboratory tests at the time of diagnosis in a series of 240 patients. Medicine 2005;84:277-90.

46. Bley TA, Weiben O, Uhl M, Vaith P, Schmidt D, Warnatz K, et al. Assessment of the cranial involvement pattern of giant cell arteritis with $3 \mathrm{~T}$ magnetic resonance imaging. Arthritis Rheum 2005;52:2470-7.

47. Liu K, Fang YY, Deng Y, Liu W, Wang MF, Ma JP, et al. Clinical characteristics of novel coronavirus cases in tertiary hospitals in Hubei Province. Chin Med J 2020;133:1025-31.

48. Wu C, Chen X, Cai Y, Xia J, Zhou X, Xu S, et al. Risk factors associated with acute respiratory distress syndrome and death in patients with coronavirus disease 2019 pneumonia in Wuhan, China. JAMA Intern Med 2020;180:934-43.

49. Cheng Y, Luo R, Wang K, Zhang M, Wang Z, Dong L, et al. Kidney disease is associated with in-hospital death of patients with COVID-19. Kidney Int 2020;97:829-38.

50. Foroozan R, Danesh-Meyer H, Savino PJ, Gamble G, Mekari-Sabbagh ON, Sergott RC. Thrombocytosis in patients with biopsy-proven giant cell arteritis. Ophthalmology 2002; 109:1267-71.

51. Brittain GP, McIlwaine GG, Bell JA, Gibson JM. Plasma viscosity or erythrocyte sedimentation rate in the diagnosis of giant cell arteritis? Br J Ophthalmol 1991;75:656-9.

52. Walvick MD, Walvick MP. Giant cell arteritis: laboratory predictors of a positive temporal artery biopsy. Ophthalmology 2011;118:1201-4.

53. Oh LJ, Wong E, Andrici J, McCluskey P, Smith J, Gill AJ. Full blood count as an ancillary test to support the diagnosis of giant cell arteritis. Intern Med J 2018;48:408-13.

54. El-Dairi MA, Chang L, Proia AD, Cummings TJ, Stinnett SS, Bhatti MT. Diagnostic algorithm for patients with suspected giant cell arteritis. J Neuroophthalmol 2015;35:246-53.

55. Grossman C, Barshack I, Koren-Morag N, Ben-Zvi I, Bornstein G. Baseline clinical predictors of an ultimate giant cell arteritis 
diagnosis in patients referred to temporal artery biopsy. Clin Rheumatol 2016;35:1817-22.

56. Nesher G, Nesher R, Mates M, Sonnenblick M, Breuer GS. Giant cell arteritis: intensity of the initial systemic inflammatory response and the course of the disease. Clin Exp Rheumatol 2008;26:S30-4.

57. Martinez-Lado L, Calviño-Díaz C, Piñeiro A, Dierssen T, Vazquez-Rodriguez TR, Miranda-Filloy JA, et al. Relapses and recurrences in giant cell arteritis: a population-based study of patients with biopsy-proven disease from northwestern Spain. Medicine 2011;90:186-93.

58. Cao B, Wang Y, Wen D, Liu W, Wang J, Fan G, et al. A trial of lopinavir-ritonavir in adults hospitalized with severe Covid-19. New Engl J Med 2020;382:1787-99.

59. Ješe R, Rotar Ž , Tomšič M, Hočevar A. The role of colour doppler ultrasonography of facial and occipital arteries in patients with giant cell arteritis: a prospective study. Eur J Radiol 2017;95:9-12.

60. Nuenninghoff DM, Hunder GG, Christianson TJ, McClelland RL, Matteson EL. Incidence and predictors of large-artery complication (aortic aneurysm, aortic dissection, and/or large-artery stenosis) in patients with giant cell arteritis: A population-based study over 50 years. Arthritis Rheum 2003;48:3522-31.

61. Becourt-Verlomme C, Barouky R, Alexandre C, Gonthier R, Laurent H, Vital Durand D, et al. [Inaugural symptoms of Horton's disease in a series of 260 patients]. [Article in French] Rev Med Interne 2001;22:631-7.

62. Zhao W, Zhong Z, Xie X, Yu Q, Liu J. Relation between chest CT findings and clinical conditions of coronavirus disease (COVID-19) pneumonia: a multicenter study. AJR Am J Roentgenol 2020;214:1072-7.
63. Wang K, Kang S, Tian R, Zhang X, Zhang X, Wang Y. Imaging manifestations and diagnostic value of chest $\mathrm{CT}$ of coronavirus disease 2019 (COVID-19) in the Xiaogan area. Clin Radiol 2020;75:341-7.

64. Xie H, Zhao J, Lian N, Lin S, Xie Q, Zhuo H. Clinical characteristics of non-ICU hospitalized patients with coronavirus disease 2019 and liver injury: a retrospective study. Liver Int 2020;40:1321-6.

65. Oiwa H, Ichimura K, Hosokawa Y, Araki K, Funaki M, Kawashima $\mathrm{M}$, et al. Diagnostic performance of a temporal artery biopsy for the diagnosis of giant cell arteritis in Japan-a single-center retrospective cohort study. Intern Med 2019;58:2451-8.

66. Berlit P. Clinical and laboratory findings with giant cell arteritis. J Neurol Sci 1992;111:1-12.

67. Gur H, Rapman E, Ehrenfeld M, Sidi Y. Clinical manifestations of temporal arteritis: a report from Israel. J Rheumatol 1996; 23:1927-31

68. van der Geest KSM, Sandovici M, Brouwer E, Mackie SL. Diagnostic accuracy of symptoms, physical signs, and laboratory tests for giant cell arteritis: a systematic review and meta-analysis. JAMA Intern Med 2020;180:1295-1304.

69. Prior JA, Ranjbar H, Belcher J, Mackie SL, Helliwell T, Liddle J, et al. Diagnostic delay for giant cell arteritis - a systematic review and meta-analysis. BMC Med 2017;15:120.

70. Vaira LA, Salzano G, Deiana G, De Riu G. Anosmia and ageusia: Common findings in COVID-19 patients. Laryngoscope 2020;130:1787.

71. Smetana GW, Shmerling RH. Does this patient have temporal arteritis? JAMA 2002;287:92-101. 